\title{
多品種少量生産におけるエネルギ原単位の定式化 \\ Formulation of Energy Consumption per Production Throughput under High-mix Low-volume Production
}

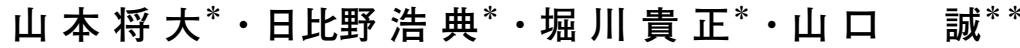 \\ Masahiro YAMAMOTO, Hironori HIBINO, Takamasa HORIKAWA and Makoto YAMAGUCHI
}

(Received March 1. 2018)

\begin{abstract}
Recently, getting more reduction of energy consumption is attracting the attention not only of society, but also of industries. The other hand, the industries need to apply high-mix low-volume productions in response to customer needs. Therefore, the industries have to simultaneously realize productivity applying high-mix low-volume productions, and reduction of energy consumption. Previous studies conducted on the formulation of energy consumption per production throughput. However, research on the formulation of considering production for the high-mix low-volume production line has not been conducted.

In this study, we propose a formulation of relationship between production conditions and energy consumption per production throughput for high-mix low-volume productions. We consider lot size, cycle time, and setting-up time as production conditions. Case studies for the printed circuit board production are carried out to verify our proposed formulation.
\end{abstract}

Key Words: Manufacturing System Simulation, Energy Consumption, Production Condition, High Mix Low Volume Production

\section{1. 緒言}

エネルギーの効率的な利用は、あらゆる分野にお いて必須の課題となりつつある。産業界において、 2014 年 4 月に施行されたエネルギーの使用の合理化 等に関する法律（省エネ法）の改正により、年間 $1500 \mathrm{kl}$ 以上のエネルギーを使用する事業者を対象に、 エネルギー消費原単位を年平均 $1 \%$ 以上低減するこ とが制度化 1)され、生産活動における消費エネルギ 一量の事前評価、および、消費電力を考慮した工場 管理、生産計画が必要となっている 2)。また、2015 年 12 月の COP21 において締結されたパリ協定によ り、すべての国に温室効果ガスの削減目標の提出、 および、目標達成のための対策を措置することが義 務化された ${ }^{3)}$ 。その結果、国内における対応策の 1 つ として、産業界における省エネルギ一化を実現する ために、製造プロセスにおけるエネルギーの使用状 況を解析し、エネルギーを効率的に利用するための エネルギーマネジメント技術の革新を実現すること が挙げられている ${ }^{4)}$ 。従来、生産性の事前評価に関 して、生産システムシミュレーションを利用する事 前評価手法が進展していた ${ }^{5-12)}$ 。しかしながら、世界 的な背景により、今後の産業界においては、生産性 に加え消費エネルギー量を考慮する事前評価手法や 新しい生産計画・マネジメントの確立が必要となる 13-15)。生産性と消費エネルギー量を考慮する事前評 価手法については、生産性と消費エネルギー量によ
つて算出されるエネルギー原単位を用いて、生産シ ステム設計時に生産性と消費エネルギ一量を同時算 出する手法の提案 16)17) が行われている。また、生産 性と消費エネルギー量を考慮する生産計画・マネジ メント手法については、生産ラインにおけるエネル ギー原単位とロットサイズの関係に着目し、エネル ギー原単位のロットサイズ依存性に関する定式化を 行い、理論の妥当性が確認されている ${ }^{18-20) 。}$

他方で、近年消費者ニーズが多様化し、かつ、製 品のライフサイクルが短期化している。これらによ り、企業は単品種生産ラインから、ニーズや技術の 変化に即した多品種少量生産ラインへの移行を進め ており、近年では生産における優位性として多品種 少量生産を挙げる企業が多くなっている ${ }^{21)}$ 。したが って、多品種少量生産ラインにおける生産性と消費 エネルギー量を考慮する生産計画・マネジメント手 法が必要となっているが、これまでの研究において、 実施されていない。

そこで、本研究では、生産性と消費エネルギー量 を考慮する生産計画・マネジメント手法として、多 品種少量生産ラインにおける生産条件とエネルギー 原単位の関係性について理論的な定式化を行う。そ の際、生産条件として、生産計画における重要な指 標であるロットサイズ、各設備のサイクルタイム、 および各設備の段取時間を考慮する。また、プリン 卜基板製造ラインを対象にケーススタディを実施し、 提案する理論の妥当性について検証を行う。

*東京理科大学大学院 理工学部 経営工学科専攻（†278-8510 千葉県野田市山崎2641)

Graduate School of Sciece and Technology, Tokyo University of Science (2641 Yamazaki, Noda-shi, Chiba 278-8510, Japan)

***秋田大学大学院 理工学研究科 システムデザイン工学専攻 機械工学コース（†010-8502 秋田市手形学園町1 番1 号)

Graduate School of Engineering Science, Faculty of Engineering Science, Department of System Design Engineering, Mechanical Engineering Course, Akita University

(1-1 Tegatagakuenmachi, Akita-shi, Akita 010-8502, Japan) 


\section{2. 多品種少量生産ラインにおける課題の整理}

本章では、多品種少量生産ラインにおいて考慮す べき生産条件を整理し、課題を述べる。

多品種少量生産ラインにおいては、需要の変動に よる欠品に対応するため一定の製品在庫を保有する ものの、できる限り小さい在庫量での運用が求めら れている。製造ロットサイズが大きい場合、対象口 ットの製品の製造のため、生産ラインを長時間同一 の製品製造のために割り当てることになる。その間、 他の品種の製造ができず、他の品種は久品する。ま た、製造ロットサイズが大きいと、直近の需要量よ りも多くの製品を製造するため、製品在庫量が増え る。そのため、品種ごとの需要量の比率を取り、そ の比率を利用してロットサイズを決定し、製造する ことで、久品や在庫量を少なくする平準化生産を実 施することが多い。平準化生産におけるロットサイ ズの決定については、中長期の需要量予測から比率 を決め、日単位、時間単位、分単位などの時間分割 単位でロットサイズを決定する(Fig.1)。一般的には、 時間分割単位は可能な限り小さくすることが多い。

これらより、多品種少量生産における生産条件とし て、平準化生産を前提とした品種ごとに異なるロッ トサイズを考慮する必要がある。

次に、平準化生産において、各設備における作業 内容は品種により異なるため、各設備におけるサイ クルタイムは、品種により異なる(Fig.2)。サイクルタ イムが品種ごとに異なる場合、設備間に生産能力の 差が生じ、スタービングやブロッキングなどの現象 が生産ラインで発生するため、ものの流れに影響を 与える。

また、平準化生産による生産ラインの各設備は、 品種切り替えの段取替えが頻繁に発生し、生産性の 低下が起こり易い。その際、品種切替の段取時間は、 品種によって異なることが多い(Fig.2)。

これらより、多品種少量生産ラインにおける生産 条件として、生産ラインの各設備では、段取時間、 サイクルタイムを考慮する必要がある。また、これ

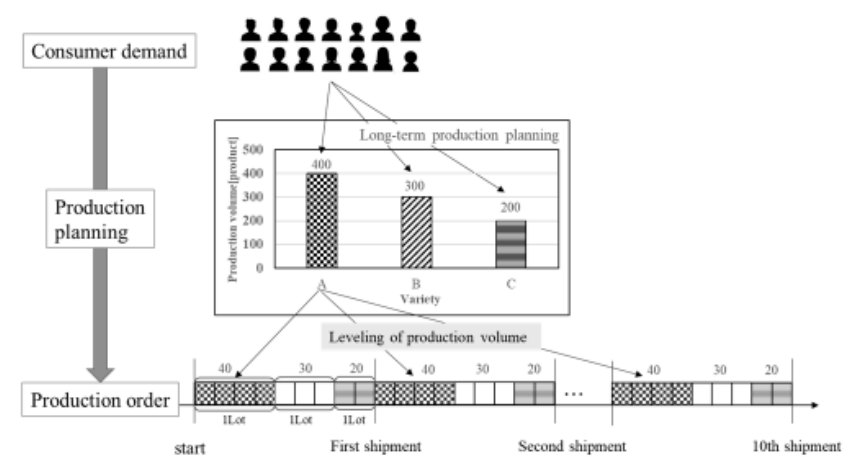

Fig.1 Lotsize in high-mix low-volume production line.
ら 3 つの生産条件は生産性に影響する。エネルギー 原単位は生産量とエネルギー消費量から算出するた め、3つの生産条件はエネルギー原単位に影響する。 しかしながら、多品種少量生産ラインにおけるこれ らの生産条件とエネルギー原単位の関係性は定量的 に評価されていない。

\section{3. 多品種少量生産ラインにおける定式化}

定式化のための前提条件

以下に本研究の定式化のための前提条件を定義する。

- 設備は直列に結ばれている。

- 複数の品種を同一生産ラインで製造する。

- すべての設備は、総稼働時間 $T$ の間に、加工状 態 $T_{r}^{k}$ 、段取状態 $T_{s}^{k}$ 、待機状態 $T_{i}^{k}$ いずれかの状 態に属するものとする。（Fig.3）

(設備 1 , 設備 $2 ， \ldots$, 設備 $k ， \ldots$, 設備 $n$ )

・ロットサイズ、各設備のサイクルタイム、およ び段取時間が品種ごとに異なる。

- 稼働時間が十分に長い。

・ 各設備間にはバッファ (バッファサイズ無限 大）が存在する。

- 故障はしない。

・ 各設備状態の単位時間における消費エネルギ 一は一定である。

\subsection{1 エネルギー原単位}

製造に用いる消費エネルギーに対する生産量を評 価する代表的な指標として、エネルギー原単位の利 用が進展している。エネルギー原単位Uは、総生産量

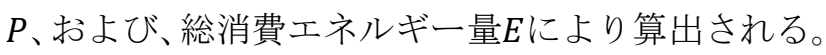

$$
\begin{array}{cl}
U=\frac{E}{P} & \\
U: & \text { エネルギー原単位 } \\
P: & \text { 総生産量 } \\
E: & \text { 総消費エネルギー量 }
\end{array}
$$

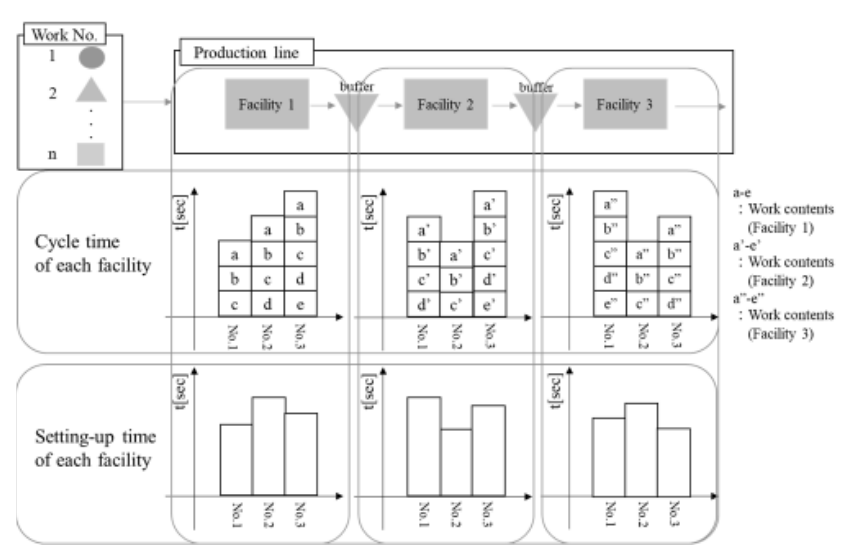

Fig.2 Cycle time and Setting-up time in high-mix lowvolume production line. 
消費エネルギーを電力とすると、エネルギー原単位 $U$ の単位は kWs/個となる。消費エネルギーおよび生 産個数の単位時間あたりの量を、消費電力e (単位時 間あたりの消費エネルギー)、および、スループット $p$ (単位時間あたりの生産個数) と呼ぶこととする。 単位時間として秒を用いると、消費電力の単位は $\mathrm{kW} 、$ スループットの単位は個/s となる。

\section{2 多品種少量生産ラインにおける生産条件}

\section{2 .1 ロットサイズ}

多品種少量生産ラインにおいて、品種ごとに異な るロットサイズを考慮する必要がある。本研究にお けるロットサイズを次のように定義する。

品種ごとのロットサイズは、生産量の比を用いて 決定される。そのため、多品種における品種ごとの 生産量 $\left\{P^{1}, P^{2}, \ldots, P^{x} \ldots, P^{n}\right\}$ の整数比を品種ごとの口 ットサイズ $\{L S(1), L S(2), \ldots, L S(x) \ldots, L S(n)\}$ とする $\left(P^{x}\right.$ : 品種 $x$ の生産量、 $L S(x)$ : 品種 $x$ のロットサイ ズ）。一度決定したロットサイズは変更しないものと する。すべての品種を 1 ロット生産するまで品種の 重複はないものとし、投入順序は問わないが、一度 決定した投入順序を繰り返すものとする。

したがって、多品種における品種 $x$ の生産割合 $P^{x} / P$ は、品種 $x$ のロットサイズ $L S(x)$ をすべての品 種におけるロットサイズの総和で除することで求め られる。

$$
\begin{array}{ll}
\frac{P^{x}}{P}=\frac{L S(x)}{\sum_{i=1}^{n} L S(i)} & \\
P^{x}: & \text { 品種 } x \text { の生産量 } \\
L S(x): \quad & \text { 品種 } x \text { のロットサイズ }
\end{array}
$$

\subsection{2 各設備のサイクルタイム}

多品種少量生産ラインにおいて、品種ごとに異な る各設備のサイクルタイムを考慮する必要がある。

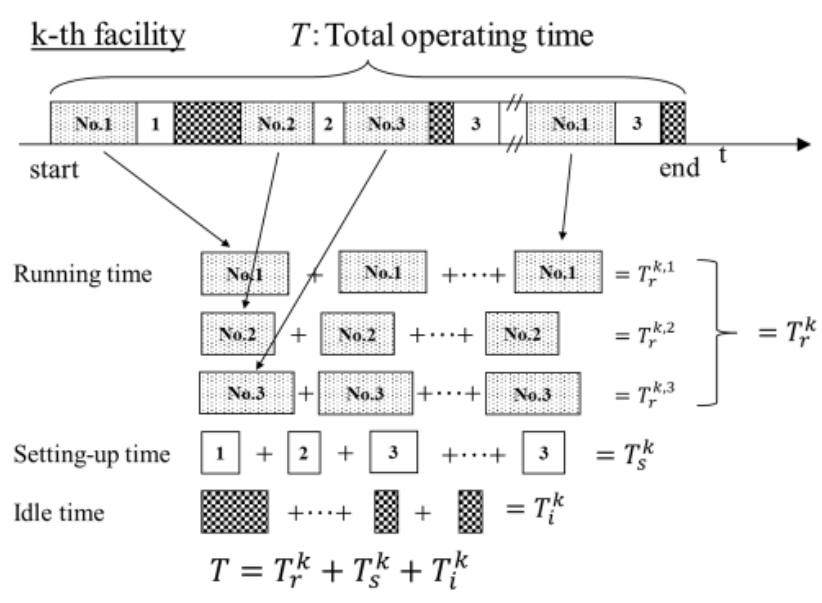

Fig.3 Relationship between total operating time and total operating time of each state in $\mathrm{k}$-th facility.
本研究における各設備のサイクルタイムを次のよう に定義する。

品種 $x$ における設備 $k$ のサイクルタイムを $1 / p_{r}^{k, x}$ (設備 $k$ における品種 $x$ のスループット $p_{r}^{k, x}$ の逆数) とあらわす。

\section{2 .3 各設備の段取時間}

多品種少量生産ラインにおいて、品種ごとに異な る各設備の段取時間を考慮する必要がある。本研究 における各設備の段取時間を次のように定義する。

品種 $x$ における設備 $k$ の段取時間を $\lambda^{k, x}$ とあらわ す。また、品種 $x$ における設備 $k$ の段取時間 $\lambda^{k, x}$ は他 の品種から品種 $x$ に段取替えを行う際、もしくは、 品種 $x$ から他の品種に段取替えを行う際の時間であ り、本研究では他の品種には依存しないものとする。

\section{3 仕掛係数}

設備間にはバッファがあり、設備間の生産能力の 差により滞りが発生する場合には、稼働終了時にバ ッファにワークが存在することになる。ここで、設 備 $k$ における総生産量 $P^{k}$ を総生産量 $P$ で除した值を 設備 $k$ における仕掛係数として以下のように定義す る。

$$
\begin{gathered}
q^{k}=\frac{P^{k}}{P} \\
q^{k}: \\
P^{k}:
\end{gathered}
$$

すなわち、仕掛係数を用いることで、各設備の生 産量 $P^{k}$ を、総生産量 $P$ を用いて表すことができる。各 設備の生産量と総生産量が同じであれば $q^{k}=1$ 、各 設備の生産量が、総生産量よりも大きい場合は、 $q^{k}>1$ となる。また、 $q^{k}$ は前行程にいくほど大きく なり、

$$
\begin{gathered}
q^{1} \geq \cdots \geq q^{k-1} \geq q^{k} \geq q^{k+1} \geq \cdots \geq q^{n} \\
=1
\end{gathered}
$$

の関係がある(Fig.4)。設備 $k$ と設備 $k+1$ の間にある バッファのサイズ $N_{b u f}^{k}$ が有限である場合には、設備 $k$ の生産個数 $P^{k}$ は、最大でも $P^{k+1}+N_{b u f}^{k}$ である。さ らに、 $n$ 個の設備がある場合には、以下のようになり、 総稼働時間を長くし、総生産量が大きくなれば、仕 掛係数は 1 となる。

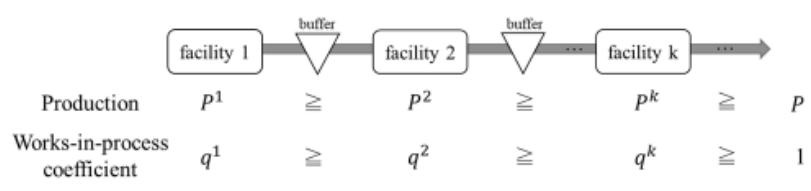

Fig.4 Works-in-process coefficient. 


$$
\begin{aligned}
& q^{k}=\frac{P^{k}}{P} \leq \frac{P^{k+1}+N_{b u f}^{k}}{P} \\
& \leq \frac{P^{k+2}+N_{b u f}^{k}+N_{b u f}^{k+1}}{P} \\
& \leq \cdots \leq \frac{P^{n}+N_{b u f}^{k}+N_{b u f}^{k+1}+\cdots N_{b u f}^{n-1}}{P} \\
&= 1+\frac{N_{b u f}^{k}+N_{b u f}^{k+1}+\cdots N_{b u f}^{n-1}}{P} \\
& N_{b u f}^{k}: \quad \begin{array}{c}
\text { 設備 } k \text { と設備 } k+1 の \text { 間にある } \\
\text { バッファのサイズ }
\end{array}
\end{aligned}
$$

また、バッファのサイズ $N_{b u f}^{k}$ が無限である場合には、 式（5）より仕掛係数は 1 以上となる。

\section{4 設備 $k$ の各状態 $m$ に関する時間 $T_{m}^{k}$}

\subsection{1 設備 $k$ の総加工時間 $T_{r}^{k}$}

多品種少量生産ラインにおいて、設備 $k$ の総加工 時間 $T_{r}^{k}$ は設備 $k$ における品種ごとの加工時間の総和 であることから設備 $k$ にお括る品種 $x$ の加工時間 $T_{r}^{k, x}$ を用いると以下のようになる。

$$
\begin{array}{ll}
T_{r}^{k}=\sum_{x=1}^{n} T_{r}^{k, x} & (6) \\
T_{r}^{k}: & \text { 設備 } k \text { の総加工時間 } \\
T_{r}^{k, x}: & \text { 設備 } k \text { における品種 } x \text { の加工時間 }
\end{array}
$$

設備 $k$ における品種 $x$ の加工時間 $T_{r}^{k, x}$ は、設備 $k$ に おける品種 $x$ の生産量 $P^{k, x}$ と設備 $k$ における品種 $x$ のサイクルタイム $1 / p_{r}^{k, x}$ の積で求められることから、 以下のようになる。

$$
\begin{array}{cl}
T_{r}^{k, x}=\frac{P^{k, x}}{p_{r}^{k, x}}= & \frac{P^{k}}{P} \frac{P^{x}}{P} \frac{P}{p_{r}^{k, x}}=q^{k} \frac{L S(x)}{\sum L S(i)} \frac{P}{p_{r}^{k, x}} \quad \text { (7) } \\
P^{k, x}: & \text { 設備 } k \text { における品種 } x \text { の生産量 } \\
p_{r}^{k, x}: & \text { 設備 } k \text { における品種 } x \text { の } \\
& \text { スループット }
\end{array}
$$

したがって、設備 $k$ における総加工時間は以下の ようにあらわされる。

$$
T_{r}^{k}=q^{k} P \sum_{x=1}^{n}\left(\frac{L S(x)}{\sum L S(i)} \frac{1}{p_{r}^{k, x}}\right)
$$

\subsection{2 設備 $k$ の総段取時間 $T_{s}^{k}$}

設備 $k$ の総段取時間 $T_{s}^{k}$ も同様にして、品種ごとの 段取時間の総和であることから、設備 $k$ における品 種 $x$ の段取時間 $T_{s}^{k, x}$ を用いると、以下のようになる。

$$
T_{s}^{k}=\sum_{x=1}^{n} T_{s}^{k, x}
$$
$T_{s}^{k}:$
設備 $k$ の総段取時間
$T_{s}^{k, x}: \quad$ 設備 $k$ における品種 $x$ の段取時間

設備 $k$ における品種 $x$ の段取時間 $T_{s}^{k, x}$ は、設備 $k$ に おける品種 $x$ の段取回数と設備 $k$ における品種 $x$ の 1 回の段取に要する時間 $\lambda^{k, x}$ の積である。設備 $k$ にお ける品種 $x$ の段取回数は設備 $k$ における品種 $x$ の生 産量 $P^{k, x} L S(x)$ で除することにより求められるた め、設備 $k$ における品種 $x$ の段取時間 $T_{s}^{k, x}$ は、以下 のようになる。

$$
\begin{gathered}
T_{S}^{k, x}=\frac{P^{k, x} \lambda^{k, x}}{L S(x)}=\frac{P^{k}}{P} \frac{P^{x}}{P} \frac{\lambda^{k, x}}{L S(x)}=\frac{q^{k} P \lambda^{k, x}}{\sum L S(i)} \quad(10) \\
\lambda^{k, x}: \quad \begin{array}{c}
\text { 設備 } k \text { における品種 } x \text { の } 1 \text { 回の } \\
\text { 段取に要する時間 }
\end{array}
\end{gathered}
$$

したがって、設備 $k$ における総段取時間は以下の ようにあらわされる。

$$
T_{s}^{k}=q^{k} P \sum_{x=1}^{n}\left(\frac{\lambda^{k, x}}{\sum L S(i)}\right)
$$

3.4.3 設備 $k$ の総待機時間 $T_{i}^{k}$

設備 $k$ の総待機時間 $T_{i}^{k}$ は総稼働時間 $T$ から、総加 工時間 $T_{r}^{k}$ 、総段取時間 $T_{s}^{k}$ を除いた值であり、以下の ようにあらわされる。

$$
\begin{array}{ll}
T_{i}^{k}=T-T_{r}^{k}- & T_{s}^{k} \\
T_{i}^{k}: & \text { 設備 } k \text { の総待機時間 } \\
T: & \text { 総稼働時間 }
\end{array}
$$

\section{5 設備 $k$ の消費エネルギー}

設備 $k$ の加工状態における、消費電力を $e_{r}^{k}$ 、段取状 態における消費電力を $e_{s}^{k}$ 、待機状態における消費電 力を $e_{i}^{k}$ とすると、設備 $k$ の消費エネルギー $E^{k}$ は、以下 のようにあらわされる。

$$
\begin{array}{cc}
E^{k}=e_{r}^{k} T_{r}^{k}+ & e_{s}^{k} T_{s}^{k}+e_{i}^{k} T_{i}^{k} \\
E^{k}: & \text { 設備 } k \text { の消費エネルギー } \\
e_{r}^{k}: & \text { 設備 } k \text { の加工状態における } \\
& \text { 消費電力 } \\
e_{s}^{k}: & \text { 段取状態における消費電力 } \\
e_{i}^{k}: & \text { 待機状態における消費電力 }
\end{array}
$$

\section{6 設備 $k$ のエネルギー原単位}

設備 $k$ のエネルギー原単位 $U^{k}$ を以下のように定義 する。

$$
U^{k}=\frac{E^{k}}{P}
$$


ここで、生産ライン全体のスループット $p$ は、総生産 量 $P$ を総稼働時間 $T$ で除することにより求められる ため、以下のようにあらわされる。

$$
p=\frac{P}{T}
$$

したがって、 $U^{k} は$ 式 (8)、（11）、（12）、（14）およ び（15）より以下のようにあらわされる。

$$
\begin{aligned}
& U^{k}=\frac{1}{P}\left(e_{r}^{k} T_{r}^{k}+e_{s}^{k} T_{s}^{k}+e_{i}^{k} T_{i}^{k}\right) \\
& =q^{k}\left(e_{r}^{k} \sum_{x=1}^{n}\left(\frac{L S(x)}{\sum L S(i)} \frac{1}{p_{r}^{k, x}}\right)\right. \\
& \left.\quad+e_{s}^{k} \sum_{x=1}^{n}\left(\frac{\lambda^{k, x}}{\sum L S(i)}\right)\right) \\
& +e_{i}^{k}\left(\frac{1}{p}-q^{k} \sum_{x=1}^{n}\left(\frac{L S(x)}{\sum L S(i)} \frac{1}{p_{r}^{k, x}}\right.\right. \\
& \left.\quad+\frac{\lambda^{k, x}}{\left.\sum_{L S(i)} L\right)}\right) \\
& \quad \text { 生産ライン全体のスループット }
\end{aligned}
$$

式（16）より、多品種少量生産ラインにおける設備 $k$ のエネルギー原単位 $U^{k}$ を生産ラインの基本情報で ある品種ごとのロットサイズ $L S(x)$ 、品種ごとの各設 備のサイクルタイム $1 / p_{r}^{k, x}$ 、段取時間 $\lambda^{k, x}$ 、消費電力 $e^{k}$ 、および、未知の変数である仕掛係数 $q^{k}$ 、スルー プット $p$ 用いてあらわすことができた。

\section{7 仕掛係数 $q^{k}$ とスループット $p$ の算出方法}

まず、設備 $k$ のスループット $p^{k}$ は、設備 $k$ の総生産 量 $P^{k}$ を総稼働時間 $T$ で除することで求められるため、 以下のようになる。

$$
\begin{gathered}
p^{k}=\frac{P^{k}}{T} \\
p^{k}:
\end{gathered} \quad \text { 設備 } k \text { のスループット }
$$

次に、仕掛係数 $q^{k}$ は、設備 $k$ のスループット $p^{k}$ 、およ び、生産ライン全体のスループット $p$ を用いると、式

（3）より以下のように書き換えられる。

$$
q^{k}=\frac{P^{k}}{P}=\frac{P^{k} / T}{P / T}=\frac{p^{k}}{p}
$$

式（18）は仕掛係数 $q^{k}$ とスループット $p$ の関係性をあ らわしている。式 (18) より、 $q^{k}$ また $p$ のどちらか 一方の変数の夕求められる場合においても、 $p^{k}$ を求 めることができれば、もう一方の変数を求められる ことがわかる。
また、式（16）であらわされる項を次のように $p_{0}^{k}$ と 定義する。

$$
p_{0}^{k}=\left(\sum_{x=1}^{n}\left(\frac{L S(x)}{\sum L S(i)} \frac{1}{p_{r}^{k, x}}+\frac{\lambda^{k, x}}{\sum L S(i)}\right)\right)^{-1}
$$

$p_{0}^{k}: \quad$ 設備 $k$ が単独で稼㗢した際のスループット

ここで、設備 $k$ のスループット $p^{k}$ は、設備 $k$ より前 設備にある設備 $k^{\prime}\left(k^{\prime}<k\right)$ が設備 $k$ より性能の悪い

(設備が単独で稼働した場合のスループット $p_{0}$ が小 さい、すなわち、 $\left.p_{0}^{k \prime}<p_{0}^{k}\right)$ 場合、設備 $k$ は、供給さ れるワークがなく、加工が停止する状態（スタービ

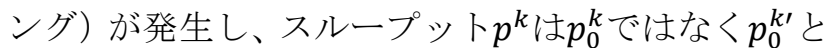
なる。また、設備 $k^{\prime}\left(k^{\prime}<k\right)$ が設備 $k$ より性能が良 い $\left(p_{0}^{k \prime}>p_{0}^{k}\right)$ 場合、スループット $p^{k}$ は $p_{0}^{k}$ となる。し たがって、設備 $k$ とその前設備 $k-1$ の間には、式(20)、

（21）の関係が成り立つ。

$$
\begin{aligned}
& p_{0}^{k}>p^{k-1} \quad \rightarrow \quad p^{k}=p^{k-1} \\
& p_{0}^{k}<p^{k-1} \quad \rightarrow \quad p^{k}=p_{0}^{k}
\end{aligned}
$$

さらに、設備 $1 （ k=1)$ では部品は絶え間なく供給 されると仮定すると、

$$
p^{1}=p_{0}^{1}
$$

となる。したがって、式（20）～（22）より、す心゙ ての $p^{k}$ を決定することができる。すなわち、 $p^{k}$ は、 設備 $k$ より前設備にある最も性能の悪い設備で律速 されるため、以下のようにあらわせる。

$$
p^{k}=\min \left\{p_{0}^{1}, p_{0}^{2},, p_{0}^{k}\right\}
$$

同様に、 $p$ は、生産ライン全体で最も性能の悪い設 備に律速されるため、以下のようにあらわせる。

$$
p=\min \left\{p_{0}^{1}, p_{0}^{2},,, p_{0}^{k},,, p_{0}^{n}\right\}
$$

式 (24) より、スループットpは、各設備におけるサ イクルタイム等の生産条件を用いて求めることがで きる。同様に、仕掛係数 $q^{k}$ に関しても、式（18）よ り以下のように求めることができる。

$$
q^{k}=\frac{p^{k}}{p}=\frac{\min \left\{p_{0}^{1}, p_{0}^{2},,, p_{0}^{k}\right\}}{\min \left\{p_{0}^{1}, p_{0}^{2},,, p_{0}^{k},, p_{0}^{n}\right\}}
$$

以上より、式(16)において、未知の変数であったスル 一プット $p$ 、仕掛係数 $q^{k}$ を式 (24)、(25) より求める ことが可能となる。したがって、多品種少量生産ラ インにおけるエネルギー原単位を生産ラインの基本 情報を用いて定式化することができた。 


\section{4. 多品種少量生産ラインにおける定式の検証}

本章では、3 つの生産条件とエネルギー原単位の 関係性について、3 章で提案した定式（式（16））の 妥当性の検証を行う。3 つの生産条件とは、多品種 少量生産ラインにおけるロットサイズ、各設備のサ イクルタイム、および段取時間である。

\section{1 前提条件}

今回の検証では、プリント基板製造ラインを対象 として、シミュレーションを行い、得られた仮想的 実データを用いて妥当性を検証する。シミュレーシ ヨンは、先行研究において、生産性と消費エネルギ 一量を同時に事前評価するシミュレーションシステ ムを参考に、生産システムシミュレーションソフト である WITNESS 22 を用いて構築した。生産システム シミュレーションは、生産システムをコンピュータ 上の仮想モデルとして模擬的に表現し、ワークなど のものの流れ方などを、離散的に時刻を進めながら 擬似実現する。すなわち、実際の生産システムにお いて、ものが必要とする処理時間を、経過を追いな がら模擬的に実験できるものである。今回の検証で は、対象生産ラインの一部であるはんだ印刷設備、 マウンター設備、はんだリフロー設備をモデル化す る。はんだ印刷設備を $k=1$ 、マウンター設備を $k=$ 2、および、はんだリフロー設備を $k=3$ とし、各設 備の前にそれぞれバッファが存在、生産する品種は 3 種類 (Product 1,Product 2,Product 3) とする。はん だ印刷設備、マウンター設備、および，はんだリフ ロー設備のシミュレーションモデルは、加工状態、

段取状態、待機状態の 3 つの状態のいずれかに属す るものとする。Fig.5 に検証を行う生産ラインのモデ ルを示す。消費エネルギーとして、消費電力を評価 する。Table 1 に各設備の単位時間における状態ごと の消費電力を示す。

ケーススタディのシナリオに関しては、今回考慮 した 3 つ生産条件とエネルギー原単位の関係性を 検証するため、以下の 3 つのシナリオを実施した。

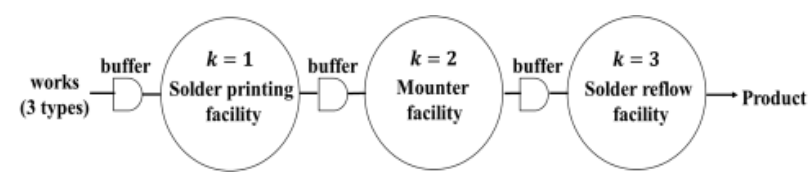

Fig.5 Model of semiconductor manufacturing line.

Table 1 Energy consumption per unit time for each state.

\begin{tabular}{ccccc}
\hline & & \multicolumn{3}{c}{ facility } \\
\cline { 3 - 5 } variable & & Printer & Mounter & Reflow \\
& & $k=1$ & $k=2$ & $k=3$ \\
\hline$e_{r}^{k}$ & {$[\mathrm{~kW}]$} & 1.25 & 3.75 & 3.00 \\
$e_{s}^{k}$ & {$[\mathrm{~kW}]$} & 3.00 & 1.50 & - \\
$e_{i}^{k}$ & {$[\mathrm{~kW}]$} & 0.20 & 0.20 & 3.00 \\
\hline
\end{tabular}

- シナリオ 1：ロットサイズとエネルギ一原単位 の関係性

- シナリオ 2 : マウンター設備のサイクルタイム とエネルギー原単位の関係性

- シナリオ 3 : マウンター設備の段取時間と エネルギー原単位の関係性

シナリオ 1、2、3 における生産条件をそれぞれ Table 2、Table 3、および Table 4 に示す。シミュレ ーションにおいて、確率的な変動を考慮するために、 各設備、各品種のスループット $p_{r}^{k, x}$ 、段取時間 $\lambda^{k, x}$ に 関しては、正規分布に従う乱数を用いた。シナリオ 1 において変動させるロットサイズ、シナリオ 2 に おいて変動させるマウンター設備のサイクルタイム、 シナリオ 3 において変動させるマウンター設備の段 取時間、それぞれ 6 通りを Table 5 に示す。

Table 2 Production conditions in scenario 1.

\begin{tabular}{|c|c|c|c|c|c|c|}
\hline \multirow{3}{*}{$\begin{array}{c}\text { Product } \\
\text { No. }\end{array}$} & \multirow{3}{*}{ variable } & & \multirow{3}{*}{ Lotsize } & \multicolumn{3}{|c|}{ facility } \\
\hline & & & & Printer & Mounter & Reflow \\
\hline & & & & $k=1$ & $k=2$ & $k=3$ \\
\hline \multirow{3}{*}{ Product 1} & $L S(1)$ & [product] & & - & - & - \\
\hline & $1 / p_{r}^{k, 1}$ & {$[\mathrm{~s}]$} & - & $10 \pm 0.1$ & $10 \pm 0.1$ & 10 \\
\hline & $\lambda^{k, 1}$ & [s] & - & $60 \pm 5$ & $60 \pm 5$ & - \\
\hline \multirow{3}{*}{ Product 2} & $L S(2)$ & [product] & & - & - & - \\
\hline & $1 / p_{r}^{k, 2}$ & {$[\mathrm{~s}]$} & - & $10 \pm 0.1$ & $10 \pm 0.1$ & 10 \\
\hline & $\lambda^{k, 2}$ & {$[\mathrm{~s}]$} & - & $60 \pm 5$ & $60 \pm 5$ & - \\
\hline \multirow{3}{*}{ Product 3} & $L S(3)$ & [product] & 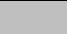 & - & - & - \\
\hline & $1 / p_{r}^{k, 3}$ & {$[\mathrm{~s}]$} & - & $10 \pm 0.1$ & $10 \pm 0.1$ & 10 \\
\hline & $\lambda^{k, 3}$ & [s] & - & $60 \pm 5$ & $60 \pm 5$ & - \\
\hline
\end{tabular}

: Variables (Table 5)

Table 3 Production conditions in scenario 2.

\begin{tabular}{|c|c|c|c|c|c|c|}
\hline \multirow{3}{*}{$\begin{array}{l}\text { Product } \\
\text { No. }\end{array}$} & \multirow{3}{*}{ variable } & & \multirow{3}{*}{ Lotsize } & \multicolumn{3}{|c|}{ facility } \\
\hline & & & & Printer & Mounter & Reflow \\
\hline & & & & $k=1$ & $k=2$ & $k=3$ \\
\hline \multirow{3}{*}{ Product 1} & $L S(1)$ & [product] & 20 & - & - & - \\
\hline & $1 / p_{r}^{k, 1}$ & {$[\mathrm{~s}]$} & - & $10 \pm 0.1$ & & 10 \\
\hline & $\lambda^{k, 1}$ & {$[\mathrm{~s}]$} & - & $60 \pm 5$ & $60 \pm 5$ & - \\
\hline \multirow{3}{*}{ Product 2} & $L S(2)$ & [product] & 15 & - & - & - \\
\hline & $1 / p_{r}^{k, 2}$ & {$[\mathrm{~s}]$} & - & $10 \pm 0.1$ & & 10 \\
\hline & $\lambda^{k, 2}$ & {$[\mathrm{~s}]$} & - & $60 \pm 5$ & $60 \pm 5$ & - \\
\hline \multirow{3}{*}{ Product 3} & $L S(3)$ & [product] & 10 & - & - & - \\
\hline & $1 / p_{r}^{k, 3}$ & {$[\mathrm{~s}]$} & - & $10 \pm 0.1$ & & 10 \\
\hline & $\lambda^{k, 3}$ & {$[\mathrm{~s}]$} & - & $60 \pm 5$ & $60 \pm 5$ & - \\
\hline
\end{tabular}

Table 4 Production conditions in scenario 3.

\begin{tabular}{|c|c|c|c|c|c|c|}
\hline \multirow{3}{*}{$\begin{array}{l}\text { Product } \\
\text { No. }\end{array}$} & \multirow{3}{*}{ variable } & & \multirow{3}{*}{ Lotsize } & \multicolumn{3}{|c|}{ facility } \\
\hline & & & & Printer & Mounter & Reflow \\
\hline & & & & $k=1$ & $k=2$ & $k=3$ \\
\hline \multirow{3}{*}{ Product 1} & $L S(1)$ & [product] & 20 & - & - & - \\
\hline & $1 / p_{r}^{k, 1}$ & {$[\mathrm{~s}]$} & - & $10 \pm 0.1$ & $10 \pm 0.1$ & 10 \\
\hline & $\lambda^{k, 1}$ & {$[\mathrm{~s}]$} & - & $60 \pm 5$ & & - \\
\hline \multirow{3}{*}{ Product 2} & $L S(2)$ & [product] & 15 & - & - & - \\
\hline & $1 / p_{r}^{k, 2}$ & {$[\mathrm{~s}]$} & - & $10 \pm 0.1$ & $10 \pm 0.1$ & 10 \\
\hline & $\lambda^{k, 2}$ & {$[\mathrm{~s}]$} & - & $60 \pm 5$ & & - \\
\hline \multirow{3}{*}{ Product 3} & $L S(3)$ & [product] & 10 & - & - & - \\
\hline & $1 / p_{r}^{k, 3}$ & {$[\mathrm{~s}]$} & - & $10 \pm 0.1$ & $10 \pm 0.1$ & 10 \\
\hline & $\lambda^{k, 3}$ & {$[\mathrm{~s}]$} & - & $60 \pm 5$ & & - \\
\hline
\end{tabular}


Table 5 Variables in each scenario.

\begin{tabular}{|c|c|c|c|c|}
\hline \multicolumn{5}{|c|}{ Scenario 1} \\
\hline & & \multicolumn{3}{|c|}{ Product 1 Product 2 Product 3} \\
\hline 1 & $L S(x)$ [product] & 4 & 3 & 2 \\
\hline 2 & $L S(x)$ [product] & 8 & 6 & 4 \\
\hline 3 & $L S(x)$ [product] & 20 & 15 & 10 \\
\hline 4 & $L S(x)$ [product] & 40 & 30 & 20 \\
\hline 5 & $L S(x)$ [product $]$ & 200 & 150 & 100 \\
\hline \multicolumn{2}{|c|}{$6 \quad L S(x)$ [product $]$} & 400 & 300 & 200 \\
\hline \multicolumn{5}{|c|}{ Scenario 3} \\
\hline & & \multicolumn{3}{|c|}{ Product 1 Product 2 Product 3} \\
\hline 1 & $\lambda^{2, x}$ & 20 & 30 & 40 \\
\hline 2 & $\lambda^{2, x}$ & 30 & 40 & 50 \\
\hline 3 & $\lambda^{2, x}$ & 40 & 50 & 60 \\
\hline 4 & $\lambda^{2, x}$ & 50 & 60 & 70 \\
\hline 5 & $\lambda^{2, x}$ & 60 & 70 & 80 \\
\hline & & 70 & 80 & \\
\hline
\end{tabular}

\section{2 提案する定式の適用}

今回の検証では、はんだリフロー設備は段取替え が発生しないため、 $\lambda^{3}=0$ となる。また、仕掛係数 の定義より、 $q^{3}=1$ となる。

\subsection{1 シナリオ 1 における定式の適用}

式（16）、および、Table 1、Table 2 より、シナリ オ 1 における各設備のエネルギー原単位は、

$$
\begin{aligned}
U^{1} & =q^{1}\left(e_{r}^{1} \sum_{x=1}^{n}\left(\frac{L S(x)}{\sum L S(i)} \frac{1}{p_{r}^{1, x}}\right)+e_{s}^{1} \sum_{x=1}^{n}\left(\frac{\lambda^{1, x}}{\sum L S(i)}\right)\right) \\
& +e_{i}^{1}\left(\frac{1}{p}-q^{1} \sum_{x=1}^{n}\left(\frac{L S(x)}{\sum L S(i)} \frac{1}{p_{r}^{1, x}}+\frac{\lambda^{1, x}}{\sum L S(i)}\right)\right) \\
= & q^{1}\left(1.25 \sum_{x=1}^{n}\left(\frac{L S(x)}{\sum L S(i)} 10\right)+3.00 \sum_{x=1}^{n}\left(\frac{180}{\sum L S(i)}\right)\right) \\
& +0.20\left(\frac{1}{p}-q^{1} \sum_{x=1}^{n}\left(\frac{L S(x)}{\sum L S(i)} 10+\frac{180}{\sum L S(i)}\right)\right) \\
U^{2}= & q^{2}\left(e_{r}^{2} \sum_{x=1}^{n}\left(\frac{L S(x)}{\sum L S(i)} \frac{1}{p_{r}^{2, x}}\right)+e_{s}^{2} \sum_{x=1}^{n}\left(\frac{\lambda^{2, x}}{\sum L S(i)}\right)\right) \\
& +e_{i}^{2}\left(\frac{1}{p}-q^{2} \sum_{x=1}^{n}\left(\frac{L S(x)}{\sum L S(i)} \frac{1}{p_{r}^{2, x}}+\frac{\lambda^{2, x}}{\sum L S(i)}\right)\right) \\
= & q^{2}\left(3.75 \sum_{x=1}^{n}\left(\frac{L S(x)}{\sum L S(i)} 10\right)+1.50 \sum_{x=1}^{n}\left(\frac{180}{\sum L S(i)}\right)\right) \\
& +0.20\left(\frac{1}{p}-q^{2} \sum_{x=1}^{n}\left(\frac{L S(x)}{\sum L S(i)} 10+\frac{180}{\sum L S(i)}\right)\right) \\
U^{3} & =q^{3}\left(e_{r}^{3} \sum_{x=1}^{n}\left(\frac{L S(x)}{\sum L S(i)} \frac{1}{p_{r}^{3, x}}\right)+e_{s}^{3} \sum_{x=1}^{n}\left(\frac{\lambda^{3, x}}{\sum L S(i)}\right)\right) \\
& +e_{i}^{3}\left(\frac{1}{p}-q^{3} \sum_{x=1}^{n}\left(\frac{L S(x)}{\sum L S(i)} \frac{1}{p_{r}^{3, x}}+\frac{\lambda^{3, x}}{\sum L S(i)}\right)\right) \\
= & 3.00 \sum_{x=1}^{n}\left(\frac{L S(x)}{\sum L S(i)} 10\right)
\end{aligned}
$$

となる。ここで、式 (18) より、設備 $k$ が単独で稼働 した場合のスループット $p_{0}^{k}$ は、以下のようになる。

$$
\begin{aligned}
& p_{0}^{1}=\left(\sum_{x=1}^{n}\left(\frac{L S(x)}{\sum L S(i)} 10+\frac{180}{\sum L S(i)}\right)\right)^{-1} \\
& p_{0}^{2}=\left(\sum_{x=1}^{n}\left(\frac{L S(x)}{\sum L S(i)} 10+\frac{180}{\sum L S(i)}\right)\right)^{-1} \\
& p_{0}^{3}=\left(\sum_{x=1}^{n}\left(\frac{L S(x)}{\sum L S(i)} 10\right)\right)^{-1}
\end{aligned}
$$

式（29）～（31）より、仕掛係数 $q^{k}$ は、式 (25) より以下のように求まる。

$$
\begin{aligned}
& q^{1}=\frac{p^{1}}{p}=\frac{\min \left\{p_{0}^{1}\right\}}{\min \left\{p_{0}^{1}, p_{0}^{2}, p_{0}^{3}\right\}} \\
& =\frac{p_{0}^{1}}{p_{0}^{1}}=\frac{p_{0}^{1}}{p_{0}^{2}}=1 \\
& q^{2}=\frac{p^{2}}{p}=\frac{\min \left\{p_{0}^{1}, p_{0}^{2}\right\}}{\min \left\{p_{0}^{1}, p_{0}^{2}, p_{0}^{3}\right\}} \\
& =\frac{p_{0}^{2}}{p_{0}^{1}}=\frac{p_{0}^{2}}{p_{0}^{2}}=1 \\
& q^{3}=1
\end{aligned}
$$

また、生産ライン全体のスループットpは、式 (24) より、以下のように求まる。

$$
\begin{aligned}
& p=\min \left\{p_{0}^{1}, p_{0}^{2}, p_{0}^{3}\right\} \\
& \quad=p_{0}^{1} \\
& =\left(\sum_{x=1}^{n}\left(\frac{L S(x)}{\sum L S(i)} 10+\frac{60}{\sum L S(i)}\right)\right)^{-1}
\end{aligned}
$$

以上より、式（32）～（35）を式（26）～（28）に 代入することによって、エネルギー原単位 $U^{k}$ を品種 ごとのロットサイズ $L S(x)$ のみを用いて、以下のよう にあらわすことができる。

$$
\begin{aligned}
& U^{1}=12.5 \sum_{x=1}^{n}\left(\frac{L S(x)}{\sum L S(i)}\right)+540 \sum_{x=1}^{n}\left(\frac{1}{\sum L S(i)}\right) \\
& +0.20\left(\frac{1}{\left(\sum_{x=1}^{n}\left(\frac{L S(x)}{\sum L S(i)} 10+\frac{60}{\sum L S(i)}\right)\right)^{-1}}\right. \\
& \left.-\sum_{x=1}^{n}\left(\frac{L S(x)}{\sum L S(i)} 10+\frac{180}{\sum L S(i)}\right)\right) \\
& U^{2}=37.5 \sum_{x=1}^{n}\left(\frac{L S(x)}{\sum L S(i)}\right)+270 \sum_{x=1}^{n}\left(\frac{1}{\sum L S(i)}\right) \\
& +0.20\left(\frac{1}{\left(\sum_{x=1}^{n}\left(\frac{L S(x)}{\sum L S(i)} 10+\frac{60}{\sum L S(i)}\right)\right)^{-1}}\right. \\
& U^{3}=30 \sum_{x=1}^{n}\left(\frac{L S(x)}{\sum L S(i)}\right) \\
& +3.00\left(\frac{1}{\left(\sum_{x=1}^{n}\left(\frac{L S(x)}{\sum L S(i)} 10+\frac{6 S(x)}{\sum L S(i)} 10+\frac{180}{\sum L S(i)}\right)\right)}\right) \\
& \left.-10 \sum_{x=1}^{n}\left(\frac{L S(x)}{\sum L S(i)}\right)\right)
\end{aligned}
$$

式（36）～（38）より、ロットサイズとエネルギ 一原単位の関係性に関して定式の適用を行うことが できた。 
4.2.2 シナリオ 2 における定式の適用

式（16）、および、Table 1、Table 3 より、シナリ オ 2 における各設備のエネルギー原単位は、

$$
\begin{aligned}
U^{1} & =q^{1}\left(e_{r}^{1} \sum_{x=1}^{n}\left(\frac{L S(x)}{\sum L S(i)} \frac{1}{p_{r}^{1, x}}\right)+e_{s}^{1} \sum_{x=1}^{n}\left(\frac{\lambda^{1, x}}{\sum L S(i)}\right)\right) \\
& +e_{i}^{1}\left(\frac{1}{p}-q^{1} \sum_{x=1}^{n}\left(\frac{L S(x)}{\sum L S(i)} \frac{1}{p_{r}^{1, x}}+\frac{\lambda^{1, x}}{\sum L S(i)}\right)\right) \\
= & q^{1}\left(1.25 \sum_{x=1}^{n}\left(\frac{4}{9} \frac{1}{p_{r}^{1, x}}\right)+12.00\right) \\
& +0.20\left(\frac{1}{p}-q^{1}\left(\sum_{x=1}^{n}\left(\frac{4}{9} \frac{1}{p_{r}^{1, x}}\right)-4.00\right)\right) \\
U^{2} & =q^{2}\left(e_{r}^{2} \sum_{x=1}^{n}\left(\frac{L S(x)}{\sum L S(i)} \frac{1}{p_{r}^{2, x}}\right)+e_{s}^{2} \sum_{x=1}^{n}\left(\frac{\lambda^{2, x}}{\sum L S(i)}\right)\right) \\
& +e_{i}^{2}\left(\frac{1}{p}-q^{2} \sum_{x=1}^{n}\left(\frac{L S(x)}{\sum L S(i)} \frac{1}{p_{r}^{2, x}}+\frac{\lambda^{2, x}}{\sum L S(i)}\right)\right) \\
= & q^{2}\left(3.75 \sum_{x=1}^{n}\left(\frac{1}{3} \frac{1}{p_{r}^{2, x}}\right)+6.00\right) \\
& +0.20\left(\frac{1}{p}-q^{2}\left(\sum_{x=1}^{n}\left(\frac{1}{3} \frac{1}{p_{r}^{2, x}}\right)-4.00\right)\right) \\
U^{3}= & q^{3}\left(e_{r}^{3} \sum_{x=1}^{n}\left(\frac{L S(x)}{\sum L S(i)} \frac{1}{p_{r}^{3, x}}\right)+e_{s}^{3} \sum_{x=1}^{n}\left(\frac{\lambda^{3, x}}{\sum L S(i)}\right)\right) \\
& +e_{i}^{3}\left(\frac{1}{p}-q^{3} \sum_{x=1}^{n}\left(\frac{L S(x)}{\sum L S(i)} \frac{1}{p_{r}^{3, x}}+\frac{\lambda^{3, x}}{\sum L S(i)}\right)\right) \\
& =3.00 \sum_{x=1}^{n}\left(\frac{2}{9} \frac{1}{p_{r}^{3, x}}\right)+3.00\left(\frac{1}{p}-\sum_{x=1}^{n}\left(\frac{2}{9} \frac{1}{p_{r}^{3, x}}\right)\right)
\end{aligned}
$$

となる。ここで、式 (18) より、設備 $k$ が単独で稼働 した場合のスループット $p_{0}^{k}$ は、以下のようになる。

$$
\begin{aligned}
& p_{0}^{1}=\left(\sum_{x=1}^{n}\left(\frac{4}{9} \frac{1}{p_{r}^{1, x}}\right)+4\right)^{-1} \\
& p_{0}^{2}=\left(\sum_{x=1}^{n}\left(\frac{1}{3} \frac{1}{p_{r}^{2, x}}\right)+4\right)^{-1} \\
& p_{0}^{3}=\left(\sum_{x=1}^{n}\left(\frac{2}{9} \frac{1}{p_{r}^{3, x}}\right)\right)^{-1}
\end{aligned}
$$

式（42）～（44）より、仕掛係数 $q^{k}$ は、式（25）よ り以下のように求まる。

$$
\begin{aligned}
& q^{1}=\frac{p^{1}}{p}=\frac{\min \left\{p_{0}^{1}\right\}}{\min \left\{p_{0}^{1}, p_{0}^{2}, p_{0}^{3}\right\}} \\
&= \frac{p_{0}^{1}}{p_{0}^{1}}=\frac{p_{0}^{1}}{p_{0}^{2}} \\
&= \frac{\left(\sum_{x=1}^{n}\left(\frac{4}{9} \frac{1}{p_{r}^{x+x}}\right)+4\right)^{-1}}{\min \left\{\left(\sum_{x=1}^{n}\left(\frac{4}{9} p_{r}^{1 \times x}\right)+4\right)^{-1},\left(\sum_{x=1}^{n}\left(\frac{1}{3} \frac{1}{p_{r}^{2 x}}\right)+4\right)^{-1},\left(\sum_{x=1}^{n}\left(\frac{2}{9} p_{r}^{3 x}\right)\right)^{-1}\right\}} \\
& q^{2}=\frac{p^{2}}{p}=\frac{\min \left\{p_{0}^{1}, p_{0}^{2}\right\}}{\min \left\{p_{0}^{1}, p_{0}^{2}, p_{0}^{3}\right\}} \\
&=\frac{p_{0}^{2}}{p_{0}^{1}}=\frac{p_{0}^{2}}{p_{0}^{2}}
\end{aligned}
$$

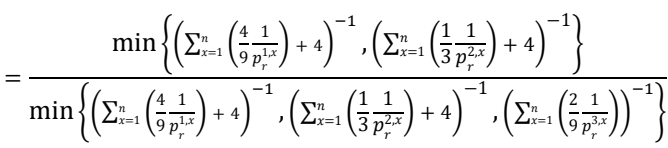

$$
\begin{aligned}
& q^{3}=1
\end{aligned}
$$

また、生産ライン全体のスループット $p$ は、式 (24) より、以下のように求まる。

$$
\left.\begin{array}{c}
p=\min \left\{p_{0}^{1}, p_{0}^{2}, p_{0}^{3}\right\} \\
=\min \left\{\left(\sum_{x=1}^{n}\left(\frac{4}{9} \frac{1}{p_{r}^{1, x}}\right)+4\right)^{-1},\left(\sum_{x=1}^{n}\left(\frac{1}{3} \frac{1}{p_{r}^{2, x}}\right)+4\right)^{-1}\right. \\
,\left(\sum_{x=1}^{n}\left(\frac{2}{9} \frac{1}{p_{r}^{3, x}}\right)\right)^{-1}
\end{array}\right\}
$$

以上より、式（45）～（47）を式（39）～（41）に 代入することによって、エネルギー原単位 $U^{k}$ を設備、 品種ごとのサイクルタイムのみを用いて、以下のよ うにあらわすことができる。

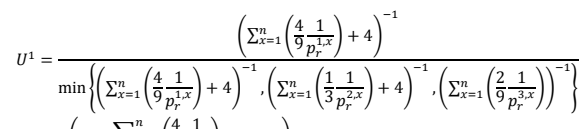

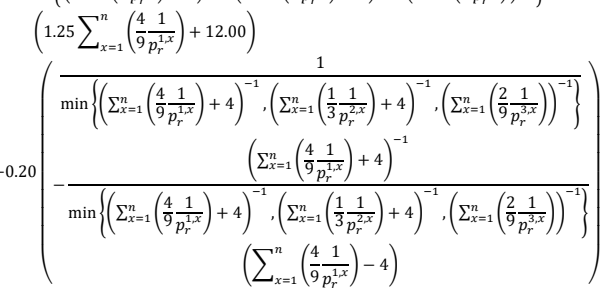

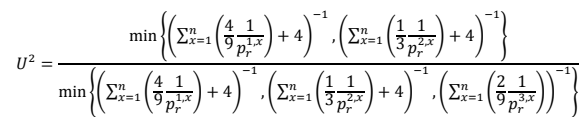

$$
\begin{aligned}
& \left(3.75 \sum_{x=1}^{n}\left(\frac{1}{3} p_{r}^{\frac{1}{2 x}}\right)+6.00\right)
\end{aligned}
$$

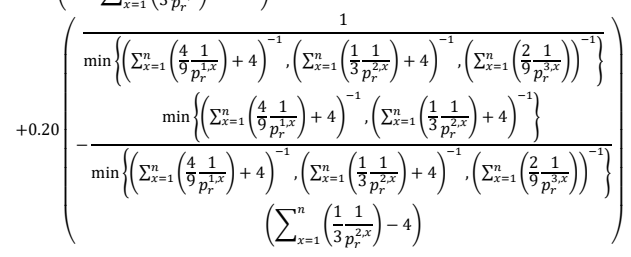

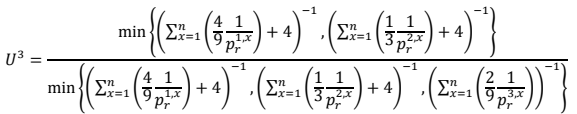

$$
\begin{aligned}
& \left(3.75 \sum_{x=1}^{n}\left(\frac{1}{3} \frac{1}{p_{r}^{2 x}}\right)+6.00\right)
\end{aligned}
$$

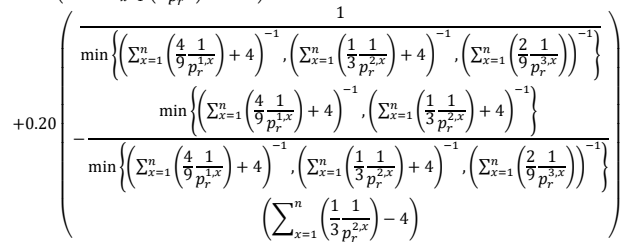

式（49）〜（51）より、ロットサイズとエネルギ 一原単位の関係性に関して定式の適用を行うことが できた。 
4.2 .3 シナリオ 3 における定式の適用

式（16）、および、Table 1、Table 4 より、シナリオ 3 における各設備のエネルギー原単位は、

$$
\begin{aligned}
U^{1} & =q^{1}\left(e_{r}^{1} \sum_{x=1}^{n}\left(\frac{L S(x)}{\sum L S(i)} \frac{1}{p_{r}^{1, x}}\right)+e_{s}^{1} \sum_{x=1}^{n}\left(\frac{\lambda^{1, x}}{\sum L S(i)}\right)\right) \\
& +e_{i}^{1}\left(\frac{1}{p}-q^{1} \sum_{x=1}^{n}\left(\frac{L S(x)}{\sum L S(i)} \frac{1}{p_{r}^{1, x}}+\frac{\lambda^{1, x}}{\sum L S(i)}\right)\right) \\
= & q^{1}\left(12.50+3.00 \sum_{x=1}^{n}\left(\frac{\lambda^{1, x}}{45}\right)\right) \\
& +0.20\left(\frac{1}{p}-q^{1}\left(10+\sum_{x=1}^{n}\left(\frac{\lambda^{1, x}}{45}\right)\right)\right) \\
U^{2}= & q^{2}\left(e_{r}^{2} \sum_{x=1}^{n}\left(\frac{L S(x)}{\sum L S(i)} \frac{1}{p_{r}^{2, x}}\right)+e_{s}^{2} \sum_{x=1}^{n}\left(\frac{\lambda^{2, x}}{\sum L S(i)}\right)\right) \\
& +e_{i}^{2}\left(\frac{1}{p}-q^{2} \sum_{x=1}^{n}\left(\frac{L S(x)}{\sum L S(i)} \frac{1}{p_{r}^{2, x}}+\frac{\lambda^{2, x}}{\sum L S(i)}\right)\right) \\
= & q^{2}\left(37.50+1.50 \sum_{x=1}^{n}\left(\frac{\lambda^{2, x}}{45}\right)\right) \\
& +0.20\left(\frac{1}{p}-q^{2}\left(10+\sum_{x=1}^{n}\left(\frac{\lambda^{2, x}}{45}\right)\right)\right) \\
U^{3} & =q^{3}\left(e_{r}^{3} \sum_{x=1}^{n}\left(\frac{L S(x)}{\sum L S(i)} \frac{1}{p_{r}^{3, x}}\right)+e_{s}^{3} \sum_{x=1}^{n}\left(\frac{\lambda^{3, x}}{\sum L S(i)}\right)\right) \\
& +e_{i}^{3}\left(\frac{1}{p}-q^{3} \sum_{x=1}^{n}\left(\frac{L S(x)}{\sum L S(i)} \frac{1}{p_{r}^{3, x}}+\frac{\lambda^{3, x}}{\sum L S(i)}\right)\right) \\
= & 30.0+3.00\left(\frac{1}{p}-10\right)
\end{aligned}
$$

となる。ここで、式（18）より、設備 $k$ が単独で稼働 した場合のスループット $p_{0}^{k}$ は、以下のようになる。

$$
\begin{aligned}
& p_{0}^{1}=\left(\sum_{x=1}^{n}\left(10+\frac{\lambda^{1, x}}{45}\right)\right)^{-1} \\
& p_{0}^{2}=\left(\sum_{x=1}^{n}\left(10+\frac{\lambda^{2, x}}{45}\right)\right)^{-1} \\
& p_{0}^{3}=10^{-1}
\end{aligned}
$$

式（55）～（57）より、仕掛係数 $q^{k}$ は、式 (25) より以下のように求まる。

$$
q^{1}=\frac{p^{1}}{p}=\frac{\min \left\{p_{0}^{1}\right\}}{\min \left\{p_{0}^{1}, p_{0}^{2}, p_{0}^{3}\right\}}
$$$$
=\frac{\left(\sum_{x=1}^{n}\left(10+\frac{\lambda^{1, x}}{45}\right)\right)^{-1}}{\min \left\{\left(\sum_{x=1}^{n}\left(10+\frac{\lambda^{1, x}}{45}\right)\right)^{-1},\left(\sum_{x=1}^{n}\left(10+\frac{\lambda^{2, x}}{45}\right)\right)^{-1}, 10^{-1}\right\}}
$$

$q^{2}=\frac{p^{2}}{p}=\frac{\min \left\{p_{0}^{1}, p_{0}^{2}\right\}}{\min \left\{p_{0}^{1}, p_{0}^{2}, p_{0}^{3}\right\}}$

$$
\begin{aligned}
& =\frac{\min \left\{\left(\sum_{x=1}^{n}\left(10+\frac{\lambda^{1, x}}{45}\right)\right)^{-1},\left(\sum_{x=1}^{n}\left(10+\frac{\lambda^{2, x}}{45}\right)\right)^{-1}\right\}}{\min \left\{\left(\sum_{x=1}^{n}\left(10+\frac{\lambda^{1, x}}{45}\right)\right)^{-1},\left(\sum_{x=1}^{n}\left(10+\frac{\lambda^{2, x}}{45}\right)\right)^{-1}, 10^{-1}\right\}} \\
& q^{3}=1
\end{aligned}
$$

また、生産ライン全体のスループットpは、式 (24) より、以下のように求まる。

$$
\begin{aligned}
& p=\min \left\{p_{0}^{1}, p_{0}^{2}, p_{0}^{3}\right\} \\
& \quad=p_{0}^{1} \\
& =\left(\sum_{x=1}^{n}\left(\frac{L S(x)}{\sum L S(i)} 10+\frac{60}{\sum L S(i)}\right)\right)^{-1}
\end{aligned}
$$

以上より、式（58）～（60）を式（52）～（54）に 代入することによって、エネルギー原単位 $U^{k}$ を設備、 品種ごとの段取時間のみを用いて、以下のようにあ らわすことができる。

$$
\begin{aligned}
& U^{1}=\frac{\left(\sum_{x=1}^{n}\left(10+\frac{\lambda^{1, x}}{45}\right)\right)^{-1}}{\min \left\{\left(\sum_{x=1}^{n}\left(10+\frac{\lambda^{1, x}}{45}\right)\right)^{-1},\left(\sum_{x=1}^{n}\left(10+\frac{\lambda^{2, x}}{45}\right)\right)^{-1}, 10^{-1}\right\}} \\
& \left(12.50+3.00 \sum_{x=1}^{n}\left(\frac{\lambda^{1, x}}{45}\right)\right) \\
& +0.20\left(\begin{array}{c}
\frac{1}{\min \left\{\left(\sum_{x=1}^{n}\left(10+\frac{\lambda^{1, x} x}{45}\right)\right)^{-1},\left(\sum_{x=1}^{n}\left(10+\frac{\lambda^{2 x}}{45}\right)\right)^{-1}, 10^{-1}\right\}} \\
\frac{\left(\sum_{x=1}^{n}\left(10+\frac{\lambda^{1, x}}{45}\right)\right)^{-1}}{\min \left\{\left(\sum_{x=1}^{n}\left(10+\frac{\lambda^{2, x}}{45}\right)\right)^{-1},\left(\sum_{x=1}^{n}\left(10+\frac{\lambda^{2 x} x}{45}\right)\right)^{-1}, 10^{-1}\right\}} \\
\left(10+\sum_{x=1}^{n}\left(\frac{\lambda^{1, x}}{45}\right)\right)
\end{array}\right) \\
& U^{2}=\frac{\min \left\{\left(\sum_{x=1}^{n}\left(10+\frac{\lambda^{1, x}}{45}\right)\right)^{-1},\left(\sum_{x=1}^{n}\left(10+\frac{\lambda^{2 x}}{45}\right)\right)^{-1}\right\}}{\min \left\{\left(\sum_{x=1}^{n}\left(10+\frac{\lambda^{1, x}}{45}\right)\right)^{-1},\left(\sum_{x=1}^{n}\left(10+\frac{\lambda^{22 x}}{45}\right)\right)^{-1}, 10^{-1}\right\}} \\
& \left(37.50+1.50 \sum_{x=1}^{n}\left(\frac{\lambda^{2, x}}{45}\right)\right) \\
& +0.20\left(\begin{array}{c}
\frac{1}{\min \left\{\left(\sum_{x=1}^{n}\left(10+\frac{\lambda^{1, x} x}{45}\right)\right)^{-1},\left(\sum_{x=1}^{n}\left(10+\frac{\lambda^{2, x}}{45}\right)\right)^{-1}, 10^{-1}\right\}} \\
\frac{\min \left\{\left(\sum_{x=1}^{n}\left(10+\frac{\lambda^{1, x}}{45}\right)\right)^{-1},\left(\sum_{x=1}^{n}\left(10+\frac{\lambda^{2 x}}{45}\right)\right)^{-1}\right\}}{\min \left\{\left(\sum_{x=1}^{n}\left(10+\frac{\lambda^{2, x}}{45}\right)\right)^{-1},\left(\sum_{x=1}^{n}\left(10+\frac{\lambda^{2 x}}{45}\right)\right)^{-1}, 10^{-1}\right\}} \\
\left(10+\sum_{x=1}^{n}\left(\frac{\lambda^{2,2}}{45}\right)\right)
\end{array}\right)
\end{aligned}
$$

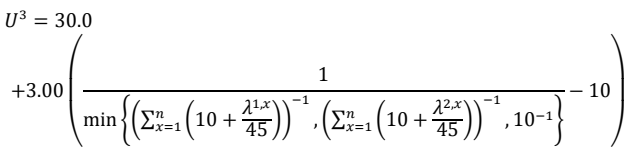

式（62）～（64）より、ロットサイズとエネルギ 一原単位の関係性に関して定式の適用を行うことが できた。

$$
\text { したがって、式 (36) 〜 (38)、(49)～(51)、(62) }
$$

〜（64）より、提案した定式から各シナリオにおけ る生産条件とエネルギー原単位の関係性を示した。

\section{3 提案する定式の検証}

本節では、提案した定式とシミュレーションによ る仮想的実データを比較し、妥当性の検証を行う。

シナリオ 1 において、式（36）～（38）より算出 した值とシミュレーションによる仮想的実データの 比較を Fig.6 に示す。横軸は品種ごとのロットサイ ズの平均の逆数、縦軸はエネルギー原単位をあらわ している。また、図中の直線は定式、マーカーは仮 
想的実データをあらわしている。

シナリオ 2 において、今回はマウンター設備のみ 品種ごとに各設備のサイクルタイムが異なる場合を 考慮する。式 (49) 〜 (51) より算出した值とシミ ユレーションによる仮想的実データの比較を Fig.7 に示す。横軸はマウンタ一設備における品種ごとの サイクルタイムの平均、縦軸はエネルギー原単位を あらわしている。また、図中の直線は定式、マーカ 一は仮想的実データをあらわしている。

シナリオ 3 において、今回はマウンター設備のみ 品種ごとに各設備の段取時間が異なる場合を考慮す る。式（62）〜（64）より算出した值とシミュレー ションによる仮想的実データの比較を Fig.8 に示

す。横軸はマウンター設備における品種ごとの段取 時間の平均、縦軸はエネルギ一原単位をあらわして いる。また、図中の直線は定式、マーカーは仮想的 実データをあらわしている。

Fig.6、Fig7、およびFig.8において、算出した值 がシミュレーションによる仮想的実データと良く一 致することから、多品種少量生産ラインにおける生 産条件とエネルギー原単位の関係性に関する定式の 妥当性を確認することができた。したがって、多品 種少量生産ラインにおける生産条件とエネルギ一原 単位の関係性を生産ラインの基本情報のみを用いて 定式化することができた。また、Fig.6から、ロッ トサイズが小さくなるにつれて、段取回数が増加す るためエネルギ一原単位が増加することがわかる。

Fig.7 から、生産ライン上のある設備のサイクルタ イムが大きくなると、他の設備のスループットが下 がり、エネルギ一原単位が増加することがわかる。

Fig.8 から、生産ライン上のある設備の段取時間が 大きくなると、他の設備のスループットが下がり、 エネルギー原単位が増加することがわかる。したが って、ある設備のサイクルタイム、段取時間が他の 設備のエネルギー原単位に与える影響を定量的に評 価できた。

\section{5. 結言}

本論文では、多品種少量生産ラインにおいて、品 種ごとに異なる生産条件とエネルギ一原単位の関係 性について理論的な定式化を行った。生産条件とは、 ロットサイズ、各設備のサイクルタイム、および各 設備の段取時間である。また、プリント基板製造 インを対象にケーススタディを実施し、提案する理 論の妥当性について検証を行った。その結果、シミ ユレーションによる仮想的実データと提案した定式 を比較し、良い一致を得ることができた。すなわち、 生産システムの設計、改善段階において、生産ライ ンの基本情報から、事前にエネルギー原単位を算出
でき、意思決定者の支援を行うことができる手法を 提案することができた。

また、今後の展望としては、品種ごとに異なる消 費エネルギー量の考慮やバッファサイズの有限化に 関する考慮を行っていく予定である。

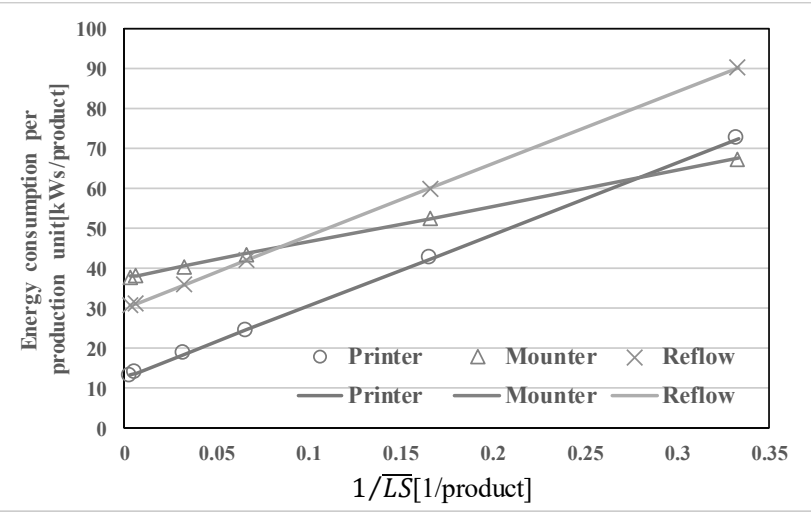

Fig.6 Virtual actual data (dots) and theoretical value(lines) in scenario 1

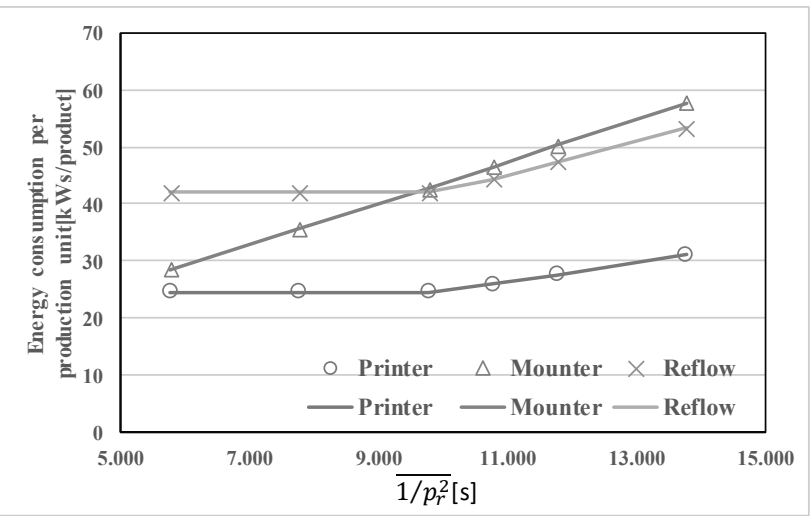

Fig.7 Virtual actual data (dots) and theoretical value(lines) in scenario 2

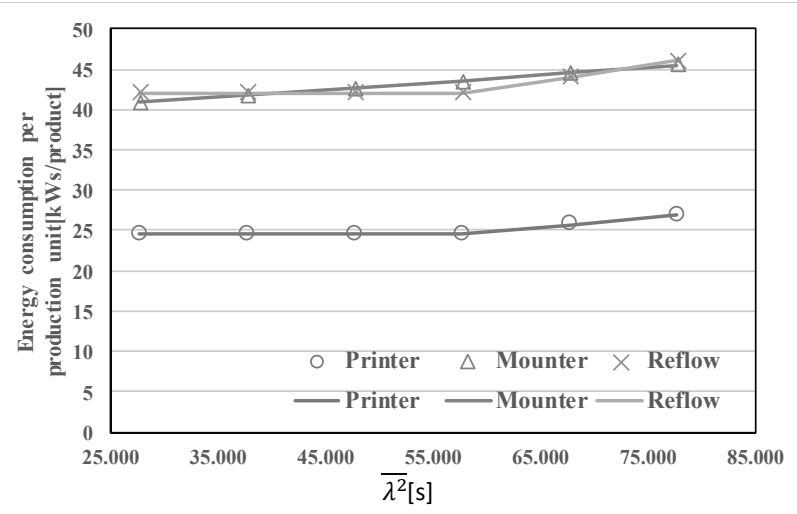

Fig.8 Virtual actual data (dots) and theoretical value(lines) in scenario 3 


\section{参考文献}

1）資源エネルギー庁，エネルギーの使用の合理化 等に関する法律 省エネ法の概要, available from

$<$ http://www.enecho.meti.go.jp/category/savin g_and_new/saving/summary/pdf/2014_ gaiyo.pdf $>$ (2016 年 12 月 1 日).

2）資源エネルギー庁，エネルギー基本計画， available

from<http://www.enecho.meti.go.jp/category/ others/basic_plan/pdf/140411.pdf >.(2018 年 4 月 6 日)

3) United Nations Framework Convention on Climate Change, Adoption of the Paris agreement, available from $<$ http://unfccc.int/resource/docs/2015/cop21/ eng/109r01.pdf $>$ (2016 年 12 月 1 日).

4）経済産業省，エネルギー革新戦略, available from <http://www.meti.go.jp/press/2016/04/ $20160419002 / 20160419002-2 . p d f>(2016$ 年 12 月 1 日).

5) H. Kim, S. S. Lee, J. H. Park, and J. G. Lee, "A model for a simulation-based shipbuilding system in a shipyard manufacturing process", International Journal of Computer Integrated manufacturing, 18-6( 2005)427441.

6) H. Kim, J. G. Lee, S. S. Lee, and J. H. Park, "A simulation-based Shipbuilding System for Evaluation of Validity in Design and Manufacturing," IEEE International Conference on Systems, Man, and Cybernetics (SMC), 1(2003)522-529.

7) C. McLean, F. Riddick, and Y. Tina, "An architecture and interfaces for distributed manufacturing simulation", Simulation, 811(2005)15-32.

8) K. Mitsuyuki, F. Kojima, H. Douba, Y. Fukuda, and E. Arai, "Simulation to design and improve Kanban system", CIRP J. manufacturing systems, 33(2004)200-206.

9) E. Williams, and H. Celik, "Analysis of conveyor systems within automotive final assembly", Proceedings of the 1998 conference on Winter simulation,(1998)915920 .

10) C. Herrmanna, S. Thiedea, S. Karab, and J. Hesselbacha, "Energy oriented simulation of manufacturing systems - Concept and application", CIRP Annals - Manufacturing Technology, 60-1(2011)45-48.

11) H. Hibino, "Method to control manufacturing cell by driving simulation model", International Journal of Automation Technology, 8-4(2014)539-549.

12) H. Hibino, Y. Fukuda, and Y. Yura, "A Synchronization Mechanism with Shared Storage Model for Distributed Manufacturing Simulation Systems", International Journal of Automation Technology, 9-3(2015)248-260.

13) Wilson, J., Arokiam A., Belaidi, H. and Ladbrook, J., A simple energy usage toolkit from manufacturing simulation data, Journal of Cleaner Production, 122(2016)266-276.

14) He, Y., Liu, B., Zhang, X., Gao, H. and Liu, $\mathrm{X}$., A modeling method of task-oriented energy consumption for machining manufacturing system, Journal of Cleaner Production, 23(2012)167-174.

15）日比野浩典, 生産システムの設計・改善・運用 段階における環境評価とシミュレーション技術 の最新動向，シミュレーション, 33-3(2014)2534.

16）佐久間徹，日比野浩典，山口誠，生産システム 設計・改善時における生産性と消費エネルギー 量のシミュレーションシステム, 日本機械学会 論文集 C 編, 79-798(2013)28-39.

17) Hibino, H., Sakuma, T. and Yamaguchi, M., Manufacturing system simulation for evaluation of productivity and energy consumption, Journal of Advanced Mechanical Design, Systems, and Manufacturing, 8-2(2014).

18）山口 誠，小林高之，日比野浩典，“生産システ ム設計・改善時における生産性と消費エネルギ 一量のシミュレーションシステム（エネルギ 一原単位とスループットの定式化に関する考 察)”，日本機械学会論文集, 82-835(2016).

19）小林高之，山口 誠，日比野浩典，“生産システ ム設計・改善時における生産性と消費エネルギ 一量のシミュレーションシステム（設備故障 を考慮する場合のエネルギー原単位のロットサ イズ依存に関する研究)”，日本機械学会論文 集, 82-835(2016).

20) T. Kobayashi, M. Yamaguchi, and H. Hibino "Lot Size Dependence for Energy Consumption per Unit of Production Throughput Considering Breakdown States in Manufacturing Line” ,Proceeding of the ACDDE2015 (Asian Conference on Design and Engineering 2015), 15-211(2015)54.

21）経済産業省，厚生労働省，文部科学省，平成 2 
7 年度 ものづくり基盤技術の振興施策 $<$ http://www.meti.go.jp/report/whitepaper/mo no/2016/honbun_pdf/pdf/gaiyou.pdf $>$ (2018 年 4 月 6 日).

22）伊藤忠テクノソリューションズ株式会社,
WITNESS, 伊藤忠テクノソリューションズの 科学・工学系情報サイト, available from $<$ http:// www.engineeringeye.com/WITNESS/>(2018 年 4 月 6 日).

代表者メールアドレス

日比野浩典 hibino@rs.tus.ac.jp 